DOI: $10.31168 / 0459-6.36$

Ю. А. Лабьнцев, Л. Л. Щавинская (Москва, Россия)

\title{
Между Шкловом и Витебском: первое внутриимперское еврейско-русское литературно-издательское делание
}

Летом 1772 г. Австрия, Пруссия и Россия заключили конвенцию о присоединении части земель Речи Посполитой к своим территориям. В результате этого первого совместного раздела огромного европейского государства к Российской империи отошла компактная пограничная его окраина, именовавшаяся «Белорусией или Белой Россией» (Новый и полный географический словарь Российского государства 1788: 123-125) с населением свыше миллиона человек, среди которых было значительное количество евреев (Анішчанка 1993: 59-68). Последние жили преимущественно в местечках и городах, таких, например, как Шклов, являвшийся в течение нескольких десятилетий одним из крупнейших центров еврейской экономической, религиозной и общекультурной жизни (Цинберг 1928: 17-44; Фельдман 1994: 28-38; Fishman 1995; Фишман 2020).

В 1778 г. императрица Екатерина II даровала Шклов генералу С. Г. Зоричу, стремившемуся приблизить местную жизнь «к уровню столичной» и действительно в течение «его двадцатилетнего владения» кое в чем почти добившегося этого (Соркіна 2010: 221). Впрочем, такое положение не исключало многочисленные раздоры среди местного населения, в том числе в еврейском сообществе, тем более что именно в данный период здесь начал активно распространяться хасидизм. В конце концов и тут, по мнению выдающегося исследователя еврейской духовной жизни С.Л.Цинберга, «рационализм и просвещение, с одной стороны, а мистицизм и религиозное благочестие, с другой, стали непримиримо враждебными лагерями» (Цинберг 1928: 44). Не только ре- 
лигиозные споры были причинами жестокой междоусобной вражды - и фринансово-экономические неурядицы приводили к самой настоящей междоусобной борьбе еврейских общин, в том числе и шкловской, еще до момента их вхождения в состав народонаселения Российской империи (Шклов 1913). В 1780-е гг. случилась в Шклове еще одна напасть, связанная с производством фральшивых векселей, а затем и распространением фальшивых ассигнаций, что «наводило на гадания о существовании подпольной типографрии» (Анищенко 1998: 109). Как бы там ни было, но «прямо или косвенно, во имя своего спасения или по наущению своих господ, <...> евреи оказались в центре вредительского ремесла» (Там же), разбирательство о котором проводилось на правительственном уровне.

Одновременно С.Г. Зорич, испытывавший постоянную нужду в деньгах на свои многочисленные инициативы экономического и культурного плана, спровоцировал острый конфликт с местным населением, в том числе с еврейским, которое стало активно жаловаться на его произвол, в том числе самому императору Павлу I. Реакцией владельца Шклова на эти жалобы явился устроенный им своего рода «еврейский погром» (Соркіна 2010: 221), разбирательство причин и последствий которого в конце концов было поручено сенатору Г. Р. Державину. Указ императора от 15 июня 1799 г. гласил: «По дошедшим до нас неоднократным жалобам о самовольных поступках в прекословие законам Нашим, против еврей и прочих в Белорусской губернии обитающих учиненных, происходящих от отставного Генерал-Лейтенанта Зорича, для прекращения сих зловредных беспорядков и для законной защиты всех тех, кои от него Зорича и в делах его от участвующих притеснения потерпели повелеваем в оную Белорусскую губернию от лица Сената Нашего послать Сенатора Державина» (Шильдер 1899: 139).

Г.Р.Державин, командировавшийся по государственным делам в Белоруссию дважды, в 1799 г., а затем 1800 г. 
(РНБ. Ф. 247. № 202. Л. 214-247), впервые вступил на белорусскую землю всего лишь через несколько дней после получения им императорского указа и 27 июня 1799 г. был уже в Витебске, а через день в Шклове. «Шкловское дело», как именовал его сам сенатор, оказалось весьма запутанным: «...много я должен буду употребить труда и времени, чтобы представить его в совершенной ясности» (Шильдер 1899: 142). Именно к этому времени, июлю и части августа 1799 г., относится без преувеличения феноменальный творческий контакт между именитым государственным сановником и литератором Г. Р. Державиным, а также местными шкловскими евреями-интеллектуалами, судить о котором позволяет ряд документов, в том числе уникальный печатный текст, созданный совместным трудом двух сторон.

Текст этот набран гражданским шрифртом на четырех листах синеватой грубой бумаги, выпущенной в центральной России в конце XVIII в.:

\section{Примьчаніе}

Предлагаются здьсь любопытнымъ охотникамъ Россійской Словесности два сочиненїя Еврейскїя, Рускими словами написанныя и по Руски переведенныя, для сравненїя произношеній и звука словъ сихъ двухъ языковъ. - Тонкое ухо может почувствовать и примътить преимущество изъ нихъ въ доброгласїи.

Въ Витебскь

1799 года (РГБ. МК Витебск-2\%99-П. Л. 1.)

Далее следует транслитерированное кириллицей сочинение на иврите:

\section{Ширь Тегило}

алъ шолымъ

Адунейну гакейсеръ гоадиръ вегахосидъ

ПАВЕЛЬ ПЕТРОВИЧЬ

горишаюнъ

гамеушель беруссенъ кулемъ. 


\section{БЕIOMЪ}

Юшевъ адунейну аль кейсъ гамлухо

шору гаїегудимъ есъ Гаширъ газе Беиръ Шкловъ имъ колъ гакгилюсъ свивсего

Брусламдъ галвано

Леадъ

Аль шимхосомъ веомунь либомъ

5557

(РГБ. МК Витебск-20/99-П. Л. 1 об. - 3 об.).

Русский, весьма вольный перевод Г. Р. Державина этого панегирика, написанного шкловскими евреями в 1797 г., помещается вслед за печатным оригиналом на иврите:

Похвальная пъснь при

возшествіи на престоль

Всепресвьтльйшаго, Державньйшаго,

Великаго Государя

Императора

Всея Россіи Павла Петровича

Перваго

воспьтая

шкловскими евреями

и съ ними сопряженнымъ Обществомъ

въ

БЪлоруссіи.

1797

(РГБ. МК Витебск-20/99-П. Л. 2-4.).

В свое время эти невзрачные, обрезанные в верхнем левом углу листки, скорее всего когда-то вплетенные в некий сборник, были обнаружены при составлении известного «Сводного каталога русской книги гражданской печати XVIII в.», но первоначально никак не связывались с именем Г. Р. Державина (Сводный каталог русской книги 1964: № 5565). Сам он в своих «объяснениях» на собственные со- 
чинения, кратко касаясь данной истории, писал, что стихотворное произведение это сочинено «шкловскими евреями в 1797 г.» (Державин 1834: 54). Оно тогда же на иврите и на немецком языке было поднесено ими в Москве Павлу I. Г. Р. Державин указывал, что в своей переводческой работе над совместным изданием он пользовался этими текстами, а также подстрочным переводом «еврейского подлинника» и непосредственными пояснениями шкловских евреев (Сочинения Державина 1865: 266-267; Сочинения Державина 1866: 657).

Практика поднесения еврейским населением панегирических сочинений русским императорам на иврите и немецком языке не была чем-то новым, в 1780-е гг., например, таковые посвящались Екатерине II. А вот издание на иврите, тем более транслитерированное кириллицей, и в русском переводе, да еще такого знатного стихотворца, являлось делом совершенно необыкновенным, настоящим еврейско-русским сотворчеством. Невозможность напечатания русского текста совместного издания в Шклове, скорее всего из-за отсутствия соответствующих шрифтов у местных типографов, деятельность которых, кстати, до сих пор почти совершенно не изучена ${ }^{1}$, заставила обратиться за помощью в только что открытую губернскую типографию в Витебске, где, в свою очередь, не было необходимых еврейских шрифтов. Именно в ней, витебской типографии, тогда же были напечатаны сохранившиеся в библиотеке Г.Р.Державина, в отличие от рассматриваемого нами издания, «стихи» в честь сенатора-стихотворца «на прибытие» его «в Белорусский город Витебск». Указана точная дата печатания этих «стихов»: «1799 года июня 30 дня» (Морозова, Шаталина, Егоров 2002: 283-284).

1 Это особенно заметно при чтении книги Д. Фишмана «Шкловцы: первые российские евреи нового времени» (Фищман 2020). 
Есть в нашем издании и еще одна замечательная, дающая возможность множества толкований особенность: публикация транслитерированного кириллицей ивритоязычного 133 псалма, необычайно вольный перевод которого Г. Р. Державиным первоначально носил очень многообещающее заглавие «Мирное общество», а затем «Братское согласие» (Сочинения Державина 1865: 262-263).

\section{Архивные источники}

РНБ Ф. 247. № 202 - Российская национальная библиотека. Отдел рукописей. Ф. 247. № 202. Л. 214-247 («Дело по белорусской ревизии»).

РГБ МК Витебск-2\%99-П — Российская государственная библиотека. МК Витебск-20/99-П. Л. 1; 1 об. - 3 об.; 2-4.

\section{Литература}

Анищенко 1998 - Анищенко E. К. Черта оседлости: Белорусская синагога в царствование Екатерины II. Минск: АРТИ-ФЕКС, 1998.

Анішчанка 1993 - Анішчанка Я. $K$. Яўрэі ўсходняй Беларусі ў канцы XVIII ст. паводле ўрадавага ўліку (крыніцазнаўчыя аспекты) // Весці АН Беларусі. Сер. гум. навук. 1993. № 4. С. 59-68.

Державин 1834 - Державин Г. Р. Объяснения на сочинения Державина. СПб.: типография Александра Смирдина, 1834.

Морозова, Шаталина, Егоров 2002 - Морозова Н. П., Шаталина Н. Н., Егоров C. К. Материалы к описанию библиотеки Г. Р. Державина // XVIII век. Сб. 22. СПб.: Наука, 2002. С. 235-287.

Новый и полный географический словарь Российского государства 1788 - Новый и полный географический словарь Российского государства. М.: Университетская типография, у Н. Новикова, 1788. Ч. 1.

Сводный каталог русской книги 1964 - Сводный каталог русской книги гражданской печати XVIII века: 1725-1800. М.: Книга, 1964. T. 2.

Соркіна 2010 - Соркіна I. Мястэчка Беларусі ў канцы XVIII - першай паловы XIX ст. Вільня: Еўрапейскі гуманітарны універсітэт, 2010.

Сочинения Державина 1865 - Сочинения Державина с объяснительными примечаниями Я. Грота. СПб.: Императорская Академия наук, 1865. Т. 2. 
Сочинения Державина 1866 - Сочинения Державина с объяснительными примечаниями Я. Грота. СПб.: Императорская Академия наук, 1866. Т. 3.

Фельдман 1994 - Фельдман Д. Из истории шкловских евреев (по материалам Российского государственного архива древних актов) // Вестник Еврейского университета в Москве. 1994. № 3 (7). С. 28-38.

Фишман 2020 - Фишлан Д. Шкловцы: первые российские евреи нового времени. М.: Книжники, 2020.

Цинберг 1928 - Цинберг C. Шклов и его «просветители» конца XVIII века // Еврейская старина. Л., 1928. Т. 12. С. 17-44.

Шильдер 1899 - Шильдер Н. К. К истории шкловской командировки Г. Р. Державина в 1799 году // Вестник всемирной истории. СПб., 1899. Декабрь, № 1. С. 138-145.

Шклов 1913 - Шклов // Еврейская энциклопедия. СПб.: Брокгауз Ефрон, 1913. Т. 16. Стб. 44-45.

Fishman 1995 - Fishman D. Russia's first modern Jews: the Jews of Shklov. New York; London: New York University Press, 1995.

\section{Between Shklov and Vitebsk: the First Intra-imperial Jewish-Russian Literary and Publishing Work}

The authors present and analyze the phenomenal fact of the joint literary and publishing work of the famous Russian writer Senator G. Derzhavin and a group of Jewish intellectuals, which took place in the summer of 1799 in the town of Shklov.

T. В. Медведева (Москва, Россия)

\section{Франтишек Иезбера в кругу русских славистов}

Чешский славист Франтишек Ян Иезбера (Jezbera, Iezbera) (1829-1901), известный в России как Федор Иванович, с вариациями написания фрамилии от Езбера/Ёзбера 